\title{
REVIEW OF MEETINGS OF THE GOVERNMENT OF THE RF IN DECEMBER 2013
}

\author{
M.Goldin
}

In December 2013, at the meetings of the Government of the Russian Federation a draft federal law which introduced into the budgetary process the components of the long-term budget planning was discussed among other things.

On December 5, the draft federal law on Amendment of the Budget Code of the Russian Federation (As Regards Long-Term Budget Planning) and Recognition as Null and Void of Individual Provisions of the Federal Law on Amendment of the Budget Code of the Russian Federation As Regards Regulation of the Budgetary Process and Bringing into Harmony of Individual Statutory Acts of the Russian Federation with the Budget Legislation of the Russian Federation was discussed at the meeting of the Government. The above draft law determines the legal basis of formation of long-term budget strategies. Development and approval of the draft law on the long-term budget planning is an important step towards introduction of long-term budgetary components in the budgetary system of the Russian Federation.

It is to be reminded that the first steps in that direction were made as early as August 2008 when the Ministry of Finance of the Russian Federation developed and published the draft of the Budget Strategy in the period till 2023. Apart from priority lines of the budget policy in the period till 2023, a key point of the Budget Strategy was efforts to develop at least approximate parameters of the expenditure side of the federal budget by sections of functional classification (as \% of GDP). Despite the fact that publication of the draft was of great importance, the document in question never became effective. A bit later, by Resolution No. 1662-r of November 17, 2008 the Concept of the Long-Term Social and Economic Development of the Russian Federation in the Period till 2020 was approved. However, due to the global financial crisis the switch-over to the long-term budget planning was postponed for an indefinite period. Despite that, in a number of regions they started to develop and approve program documents on the strategy of the long-term social and economic development.

Approval of the Program of the Government of the Russian Federation on Upgrading of Efficiency of Budget Expenditures in the Period till 2012 by Resolution No. 1101-r of June 30, 2010 of the Government of the Russian Federation made a new impact on development of the long-term budget planning. In the above program, a need to form budgets with taking into ac- count a long-term forecast of the main parameters of the budgetary system of the Russian Federation based on realistic estimates was declared as a fundamental principle of the budget policy.

In addition to the above, the Ministry of Economic Development of the Russian Federation developed and later the Government of the Russian Federation submitted to the State Duma a draft deferral law on the State Strategic Planning which specifics consisted in establishment of a long-term horizon of planning (from six years). Though the draft federal budget which set the legal frameworks of comprehensive regulation of the strategic budget planning was approved in the first reading by the State Duma of the Russian Federation in November 2012, the second reading has not taken place yet.

In such a situation, the Ministry of Finance of the Russian Federation developed and submitted to the Government of the Russian Federation the draft law on the long-term budget planning in which the concept of a long-term budget planning in the budget process was determined. It is to be noted that a key component of a long-term budget planning at all the levels of the budgetary system is the so-called budget strategies which are formed by the Russian Federation, constituent entities of the Russian Federation and municipal entities.

A "budget strategy" is determined by the draft law as a document which includes a forecast of the main parameters of the relevant budgets (consolidated budgets) of the budgetary system of the Russian Federation, indices of the financial provision of state (municipal) programs in the period of their operation, other documents which characterize budgets (consolidated budgets) of the Budgetary system of the Russian Federation, as well as the main approaches to formation of the long-term budget policy.

The budget strategy of the Russian Federation and a constituent entity of the Russian Federation is developed each six years for the period of 12 years and more on the basis of the long-term forecast of the social and economic development of the Russian Federation and a constituent entity of the Russian Federation in the relevant period. 
The budget strategy of a municipal entity is developed each three years for the period of six years and more on the basis of the long-term forecast of the social and economic development of a municipal entity in the relevant period.
Also, the draft law sets the procedure for development of a draft budget strategy.

By Resolution No.2334-r of December 11, 2013, the draft law was introduced to the State Duma of the Russian Federation. 